\title{
Synoptic measurements of ingestion rate, ingestion selectivity, and absorption efficiency of natural foods in the deposit-feeding molluscs Nucula annulata (Bivalvia) and Hydrobia totteni (Gastropoda)*
}

\author{
Glenn R. Lopez and I-Jiunn Cheng \\ Marine Sciences Research Center, State University of New York, Stony Brook, New York 11794, USA
}

\begin{abstract}
Three of the most important aspects of deposit-feeding behaviour are ingestion rate, ingestion selectivity and absorption efficiency of ingested food. The purpose of the experimental results described here is to allow estimation of these traits for animals offered natural sediments. Experiments were performed to measure ingestion rate and selectivity of inorganic, organic and microbial fractions, and absorption efficiency of ingested microbes by Nucula annulata (Bivalvia) and Hydrobia totteni (Gastropoda) offered silt-clay sediments. $N$. annulata selectively ingested the organicand bacteria-rich sediment fraction, and absorbed bacteria with $72 \%$ efficiency. H. totteni ingested the sediment non-selectively, and absorbed sediment-associated bacteria and algae with approximately $40 \%$ efficiency.
\end{abstract}

\section{INTRODUCTION}

Deposit-feeding animals ingest a complex assortment of mineral grains, organic detritus, and microorganisms. They clearly display many behavioral and morphological traits to obtain food from sediments, but it is not obvious whether these traits, when considered together, define coherent feeding strategies. Two strategies that have been suggested for deposit feeders are optimal foraging (animal increases food uptake rate with increasing food quality of sediment; Taghon, 1981, 1982) and the converse, 'compensatory' feeding (increased feeding with decreased food quality; Calow, 1975; Dammen, 1980a)

Traits important in describing deposit-feeding strategies in either case are ingestion rate, ingestion selectivity and absorption efficiency. A feeding strategy can be described in terms of how these traits interact under a variety of conditions (e.g. sediment type, food concentration in sediment). Each trait may vary independently or in tandem with the other traits;

\footnotetext{
- Contribution No. 344 from the Marine Science Research Center, State University of New York at Stony Brook, USA
}

by examining all three at the same time we should gain insight into deposit-feeding strategies. We describe here methods that allow an estimation of these components of feeding behavior for several potential foods. Lopez and Cheng (1982) described a new method that allows quantification of ingestion rate and selectivity of the organic and mineral fractions of sediment. The method was based on ${ }^{14} \mathrm{C}$ formaldehyde labelling of sedimentary organic matter (Lopez and Crenshaw, 1982) plus ${ }^{51} \mathrm{Cr}$ labelling of the sediment. We extended this method here by ${ }^{14} \mathrm{C}$ labelling of other potential food such as bacteria and algae. The method was then combined with the ${ }^{51} \mathrm{Cr} /{ }^{14} \mathrm{C}$ method of measuring absorption efficiency (Calow and Fletcher, 1972; Wightman, 1975; Cammen, 1980b).

\section{MATERIALS AND METHODS}

Collection and preparation of animals and sediments

In this study we have investigated the feeding traits of 2 deposit-feeding molluscs, the protobranch bivalve Nucula annulata and the mesogastropod Hydrobia tot- 
teni. $N$. annulata was collected from the seawater holding tank located under the Flax Pond Marine Laboratory, Long Island, New York, USA. This habitat apparently mimics a subtidal muddy environment; during a cleaning of this tank in the spring of 1981 it was found to support large populations of $N$. annulata and Nephtys sp., reminiscent of the assemblage that is dominant in portions of central Long Island Sound (Sanders, 1956). Following a cleaning of the holding tank in 1981, the densities of $N$. annulata had decreased while the abundance of Mulinia lateralis had increased (see McCall, 1977 for similar result from L. I. Sound). Adult $N$. annulata ( 4 to $5 \mathrm{~mm}$ shell length) were maintained in a recirculating seawater aquarium. The aquarium water was originally from Flax Pond; it was maintained at $15^{\circ} \mathrm{C}$ and approximately $28 \mathrm{ppt}$ salinity, and was continuously recirculated through a gravel filter. The bivalves were maintained in the aquarium on the fine $(<88 \mu \mathrm{m})$ fraction of sediment collected from the holding tank.

Hydrobia totteni was collected from an intertidal mud flat in Flax Pond, a Spartina salt marsh on Long Island, New York. H. totteni is a dominant species on this mud flat (Levinton and Bianchi, 1981). Adults ( 3 to $3.5 \mathrm{~mm}$ shell length) were kept on the fine $(<77 \mu \mathrm{m})$ fraction of sediment collected from the top centimeter of the mud flat. Portions of this sediment were stored at $2{ }^{\circ} \mathrm{C}$ for use in the feeding experiment. Both species were maintained for at least 1 mo before conducting the experiments.

\section{Radiolabelling procedures}

${ }^{14} \mathrm{C}$ labelling of sedimentary organic m a t ter. Sedimentary organic matter was labelled by the ${ }^{14} \mathrm{C}$ formaldehyde method (Lopez and Crenshaw, 1982). This labelling protocol is sufficient for estimation of ingestion rate and ingestion selectivity of organic matter, but not absorption efficiency. We assume that living microbes account for only a small fraction of sedimentary organic matter (Cammen, 1980 b). Organic matter was labelled by incubating the sediment with ${ }^{14} \mathrm{C}$ formaldehyde $\left(10 \mathrm{mCi} \mathrm{mmole}^{-1}\right.$. Amersham) at a concentration of $5 \mu \mathrm{Ci} \mathrm{cm} \mathrm{cm}^{-3}$ settled sediment. Samples were incubated for 36 to $48 \mathrm{~h}$ at 25 to $35^{\circ} \mathrm{C}$; sediment was suspended in $30 \% \mathrm{NaCl}$ during incubation to inhibit microbial activity. Unincorporated ${ }^{14} \mathrm{C}$ formaldehyde was removed by 3 centrifugerinses with filtered seawater.

${ }^{14} \mathrm{C}$ labelling of bacteria. Metabolically active bacteria in sediments were labelled by incubating the sediments with ${ }^{14} \mathrm{C}$-mixed amino acids $\left(\mathrm{U}-{ }^{14} \mathrm{C}\right.$ protein hydrolysate, $57 \mathrm{mCi} \mathrm{mAtom}^{-1}$. Amersham). Rations of radiolabel ranged from 1.6 to $1.8 \mu \mathrm{Ci} \mathrm{cm} \mathrm{cm}^{-3}$ sediment, and samples were incubated for 2 to $4 \mathrm{~h}$.
Preliminary experiments demonstrated that 95 to $98 \%$ of the uptake was due to heterotrophic microbial activity, with adsorption accounting for the remainder. Earlier microautoradiographic studies indicated that benthic algae accounted for very little uptake. Therefore, we assume that most of the ${ }^{14} \mathrm{C}$ taken up by sediment was incorporated into active bacteria.

${ }^{14} \mathrm{C}$ labelling of benthic a lgae. Metabolically active algae were labelled by incubating sediment in the light with ${ }^{14} \mathrm{C}$ bicarbonate $15 \mu \mathrm{Ci} \mathrm{cm} \mathrm{cm}^{-3}$ sediment) for $8 \mathrm{~h}$. Preliminary experiments showed that 80 to $95 \%$ of the uptake of ${ }^{14} \mathrm{C}$ bicarbonate by intertidal sediment was light-mediated. Heterotrophic uptake of $\mathrm{CO}_{2}$ by bacteria may have accounted for a small amount of uptake, but our evidence suggests that most of the ${ }^{14} \mathrm{C}$ taken up under these conditions was due to photosynthesizing algae.

${ }^{51} \mathrm{Cr}$ labelling of sediment. Each of the ${ }^{14} \mathrm{C}$ labelled sediments was also labelled with ${ }^{51} \mathrm{Cr}$ by incubating the sediment with ${ }^{51} \mathrm{CrCl}_{3}\left(5 \mu \mathrm{Ci} \mathrm{cm}{ }^{-3}\right.$ sediment). Because the ${ }^{51} \mathrm{CrCl}_{3}$ solution was prepared with $0.1 \mathrm{~N} \mathrm{HCl}$, it was neutralized upon addition to the sediment with an equal volume of $0.1 \mathrm{~N} \mathrm{NaOH}$. Under these conditions, $\mathrm{Cr}^{+++}$adsorbs to particle surfaces (Calow and Fletcher, 1972; Lopez and Cheng, 1982). Following 24-h incubation and rinsing, the sediments, now labelled with both ${ }^{14} \mathrm{C}$ and ${ }^{51} \mathrm{Cr}$, were ready for use in feeding experiments.

\section{Estimation of ${ }^{51} \mathrm{Cr}$ absorption}

Nucula annulata. Five groups of 2 animals each were allowed to feed on ${ }^{51} \mathrm{Cr}$-labelled sediment for $18 \mathrm{~h}$, and then transferred to glass liquid scintillation vials, each containing $10 \mathrm{ml}$ seawater and $1 \mathrm{~cm}^{3}$ unlabelled sediment. Vials were placed in a gamma counter to estimate the amount of ${ }^{51} \mathrm{Cr}$ ingested by the bivalves. The test animals were then periodically transferred to other vials. After each transfer, amounts of ${ }^{51} \mathrm{Cr}$ defecated and retained were measured.

Hydrobia totteni. Approximately 100 individuals were allowed to feed on ${ }^{51} \mathrm{Cr}$-sediment for 100 min. Actively feeding individuals were then transferred to unlabelled sediment for $1 \mathrm{~min}$. While they crawled on this sediment, labelled material was sloughed from foot and mantle cavity. Defecation and retention of ingested ${ }^{51} \mathrm{Cr}$ was then measured in the manner described above.

\section{Calculation of ingestion rate, ingestion selectivity, and absorption efficiency}

Nucula annulata. Because examination by fluorescense microscopy indicated that there were very few algae in the Nucula sediment, only the inorganic, 
organic, and bacterial fractions of sediment were considered in this experiment. Therefore, the experiment consisted of 2 sediment treatments, ${ }^{14} \mathrm{C}$-formaldehyde and ${ }^{14} \mathrm{C}$-amino acids labelling. To investigate ingestion rate and ingestion selectivity, individuals were transferred from unlabelled sediment to a 3-mm layer of one of the treated sediments. $N$. annulata were observed in order to determine when they began to feed. They were allowed to feed for $30 \mathrm{~min}$, and then killed and prepared for ${ }^{51} \mathrm{Cr}$ and ${ }^{14} \mathrm{C}$ counting. Gut passage time was approximately $40 \mathrm{~min}$ (Lopez and Cheng, 1982).

Ingestion selectivity can be estimated because all sedimentary material can be classified as either inorganic, organic detrital, or microbial (see legend of Table 1 for method of computation). We have used the forage ratio because its statistical analysis is more tractable than that for Ivlev's selectivity coefficient (Lopez and Cheng, 1982). (FR $=r_{1} / p_{1}$, where $r_{1}=$ proportion by weight of food type $\mathrm{i}$ ingested; $\mathrm{p}_{1}=$ proportion of food type $\mathrm{i}$ in offered sediment.

Estimation of absorption efficiency is based on the measurement of ${ }^{51} \mathrm{Cr} /{ }^{14} \mathrm{C}$ ratios of ingested food and of egested material (see Calow and Fletcher, 1972; Wightman, 1975; Cammen, 1980b). We have made a minor but important modification in this method by using ${ }^{51} \mathrm{Cr} /{ }^{14} \mathrm{C}$ of ingested material, rather than offered food, in order to avoid problems due to selective ingestion. Estimation of absorption of bacteria by Nucula annulata was based on measurement of ${ }^{51} \mathrm{Cr} /{ }^{14} \mathrm{C}$ in an ingestion group (group used for ingestion analyses) and in the feces of a parallel group that had been allowed to feed on the labelled sediment for the ingestion period, and then were transferred to unlabelled sediment. Compact fecal pellets were then collected periodically over a 43-h period, so that all labelled material was either egested or absorbed. Previous ${ }^{51} \mathrm{Cr}$ absorption experiments indicated that the digestive process took approximately $24 \mathrm{~h}$. By summing all ${ }^{51} \mathrm{Cr}$ and ${ }^{14} \mathrm{C}$ egested, a truly representative ${ }^{51} \mathrm{Cr} /{ }^{14} \mathrm{C}$ ratio for feces is obtained (Wightman, 1975). Because of the pulse-chase nature of this experiment, all time-dependent changes in specific activity are due to processes occurring in the guts of the experimental animals. A separate long-term feeding trial was conducted to measure weight-specific ${ }^{51} \mathrm{Cr}$ concentration in fecal pellets, which was used to estimate mineral grain ingestion rate (Lopez and Cheng, 1982). The feeding trial was longer and used more test animals to collect enough labelled pellets for accurate weight measurement. The results were corrected for time-dependent loss of adsorbed ${ }^{51} \mathrm{Cr}$ (losses tend to be very low), and ${ }^{51} \mathrm{Cr}$ absorbed.

For Hydrobia totteni, ingestion estimates were made by allowing groups of individuals to feed on labelled sediments for $30 \mathrm{~min}$, so no ingested material was egested. At the end of this short-term feeding period, animals were cleaned of adhering sediment and killed. In order to collect labelled $H$. totteni feces for absorption estimates, separate groups of individuals were allowed to feed on labelled sediments for $27 \mathrm{~h}$. Labelled pellets were periodically sieved and prepared for counting. Counts were corrected for time-dependent losses of isotopes from sediment.

For each species, separate groups of individuals were allowed to feed on unlabelled sediment. Fecal pellets were collected for organic content determination (weight loss on ashing).

\section{RESULTS}

Nucula annulata absorbed $72 \%$ of the ingested labelled bacteria (Table 1, Row 17). The bivalves selectively ingested the organic and bacterial fractions of the sediment, but the corresponding rejection of the inorganic fraction was not detected (Table 1, Row 18). Ingestion rate did not differ among treatments

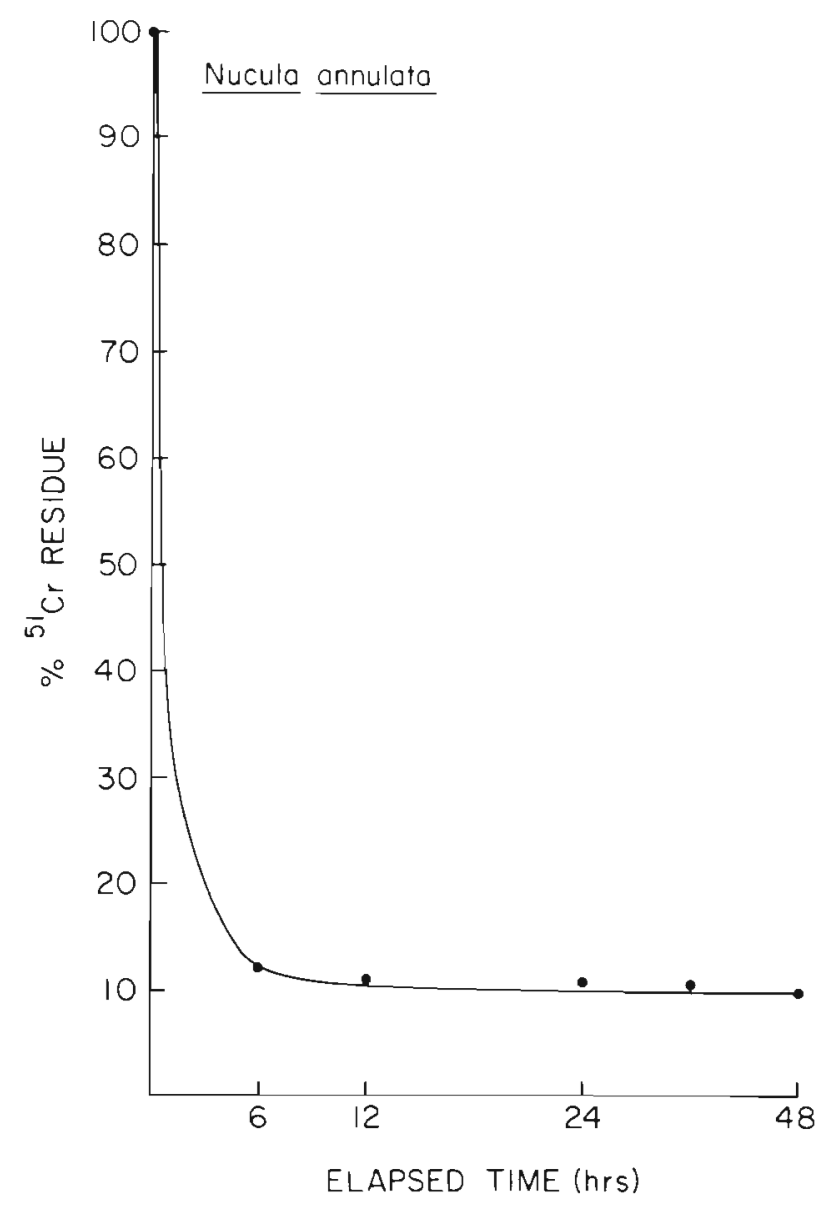

Fig. 1. Nucula annulata. Absorption of ingested ${ }^{51} \mathrm{Cr}$ 
Table 1. Nucula annulata. Feeding experiment. All values given as mean (s.d.) (sample size). Values of ${ }^{51} \mathrm{Cr}$ and ${ }^{14} \mathrm{C}$ given as estimated $\mathrm{dpm}$, counts being corrected for quench, crossover, and decay. Variance of a quotient was estimated as

$$
\cong\left(\mu_{x} / \mu_{y}\right)^{2}\left(\operatorname{var}[x] / \mu_{x}^{2}+\operatorname{var}[y] / \mu_{y}^{2}\right)
$$

Measured values

\section{Sediment}

(1) ${ }^{51} \mathrm{Cr} \mathrm{mg}{ }^{-1}$

(2) ${ }^{14} \mathrm{C} \mathrm{mg}^{-1}$

(3) ${ }^{51} \mathrm{Cr} /{ }^{14} \mathrm{C}$

(4) $\mathrm{mg}$ org $\mathrm{mg}^{-1} \mathrm{dry} w \mathrm{w}$

\section{Animals}

(5) ${ }^{51} \mathrm{Cr}$

(6) ${ }^{14} \mathrm{C}$

(7) ${ }^{51} \mathrm{Cr} /{ }^{14} \mathrm{C}$

\section{Feces}

(8) ${ }^{51} \mathrm{C} \mathrm{mg}^{-1}$, long term

(9) ${ }^{51} \mathrm{Cr} /{ }^{14} \mathrm{C}$

(10) mg inorg. $\mathrm{mg}^{-1}$ dry wt

Calculated values

(1.1) ${ }^{51} \mathrm{Cr} \mathrm{mg}^{-1}$ inorg. sed.

(12) ${ }^{14} \mathrm{C} \mathrm{mg}^{-1}$ org. sed.

(13) ${ }^{14} \mathrm{C} \mathrm{mg}^{-1}$ bacteria

(14) mg inorg. ingested

(15) mg org. ingested

(16) mg bacteria ingested

(17) \% absorption

\section{Ingestion selectivity}

(18) Forage ratio:

inorganic

organic

bacteria
I ( ${ }^{14} \mathrm{C}$-form.)

$\begin{array}{rll}62,712 & (1,189) & (\mathrm{n}=5) \\ 6,257 & (316) & (\mathrm{n}=5) \\ 10.05 & (0.68) & (\mathrm{n}=5) \\ .0946 & (.015) & (\mathrm{n}=8)\end{array}$

$10,828 \quad(3,999) \quad(n=5)$

$1,928 \quad(775) \quad(n=5)$

$5.88 \quad(1.05) \quad(n=5)$

$79,472(12,568)(\mathrm{n}=5)$

5.77

$.8896 \quad(.0022) \quad(n=5)$
II ( ${ }^{14} \mathrm{C}-$ a.a. $)$

$\begin{array}{rll}79,263 & (1,063) & (\mathrm{n}=5) \\ 9,695 & (479) & (\mathrm{n}=5) \\ 8.20 & (1.01) & (\mathrm{n}=5) \\ .0946 & (.015) & (\mathrm{n}=8)\end{array}$

$15,019 \quad(6,130) \quad(\mathrm{n}=5)$

$6,266 \quad(2,673) \quad(n=4)$

$2.46 \quad(0.62) \quad(n=4)$

$95,699 \quad(9,708) \quad(\mathrm{n}=5)$

8.82

$.8896 \quad(.0022) \quad(n=5)$

$$
\begin{array}{rrr}
89,335 & (14,129) & (\mathrm{n}=5) \\
66.142 & (12,167) & (\mathrm{n}=5) \\
.121 & (.043) & (\mathrm{n}=5) \\
.029 & (013) & (\mathrm{n}==5)
\end{array}
$$

$-1.9^{\circ}$

$(-17.7-13.9)$

$\begin{array}{rlr}107,542 & (10,916) & (\mathrm{n}=5) \\ 96,950,000 & (4,790,000) & (\mathrm{n}=5) \\ .140 & (.059) & (\mathrm{n}=5) \\ .000065 & (.000028) & (\mathrm{n}=4) \\ 72.1 & & \\ (66.0-78.2) & \end{array}$

$0.890 \quad(0.578)$

$2.046 \quad(1.58)$

$3.710 \quad(2.90)$

inorganic organic bacteria

Row (8) Corrected for ${ }^{51} \mathrm{Cr}$ absorption (10\%)

(9) 4 samples collected and counted individually, then total counts of each isotope summed

(11) Row 8/Row 10

(12) Row 2, Col. I/Row 4

(13) Row 2, Col. II/ (mg bacteria $\mathrm{mg}^{-1} \mathrm{dry}$ wt). Assume .0001 mg bacteria per mg dry wt sediment.

(14) Row 5/Row 11

(15) Col. I only, Row 6/Row 12

(16) Col. II only, Row 6/Row 13

(17) $\%$ absorption $=100\left(1={ }^{51} \mathrm{Cr} /{ }^{14} \mathrm{C}\right.$, ingested $($ Row 7$) /{ }^{51} \mathrm{Cr} /{ }^{14} \mathrm{C}$, feces [Row 9]). - absorption of organic matter calculated for purposes of discussion

(18) Ingestion selectivity. Forage ratio $=\mathrm{r} / \mathrm{p}$, where $\mathrm{r}=$ proportion by weight of food item ingested; $\mathrm{p}=$ proportion of food item in sediment. Forage ratio was calculated as follows:

(a) Normalize ingested material by dividing by ingested inorganic fraction

Inorganic $1.00(.388)(n=5)$ (s.d. reconstructed from coefficient of variation of both I and II)

Organic $0.24(.137)(\mathrm{n}=5)$ (Row 15, I/Row 14, I)

Bacteria $0.00046(.00027)(\mathrm{n}=5)$ (Row 16, II/Row 14, II)

Total $1.240046(.5814)(\mathrm{n}=5)$

$r_{\text {inorganic }}=1.00 / 1.240=.806(.4908)$

$r_{\text {organic }}=194(.143)$

$\mathrm{r}_{\text {bacteria }}=\quad .000371(.000285)$

(b) Proportion of each food type calculated for offered sediment

$\mathrm{p}_{\text {inorganic }}=.9053(.1939)(\mathrm{n}=8)$

porganic $=.0946(.0203)$

Pbactena $=.0001(.000014)$

Forage ratios were compared using an approximate t-test. Values which are not statistically different have a continuous line beneath them 
Table 2. Hydrobia totteni. Feeding experiment

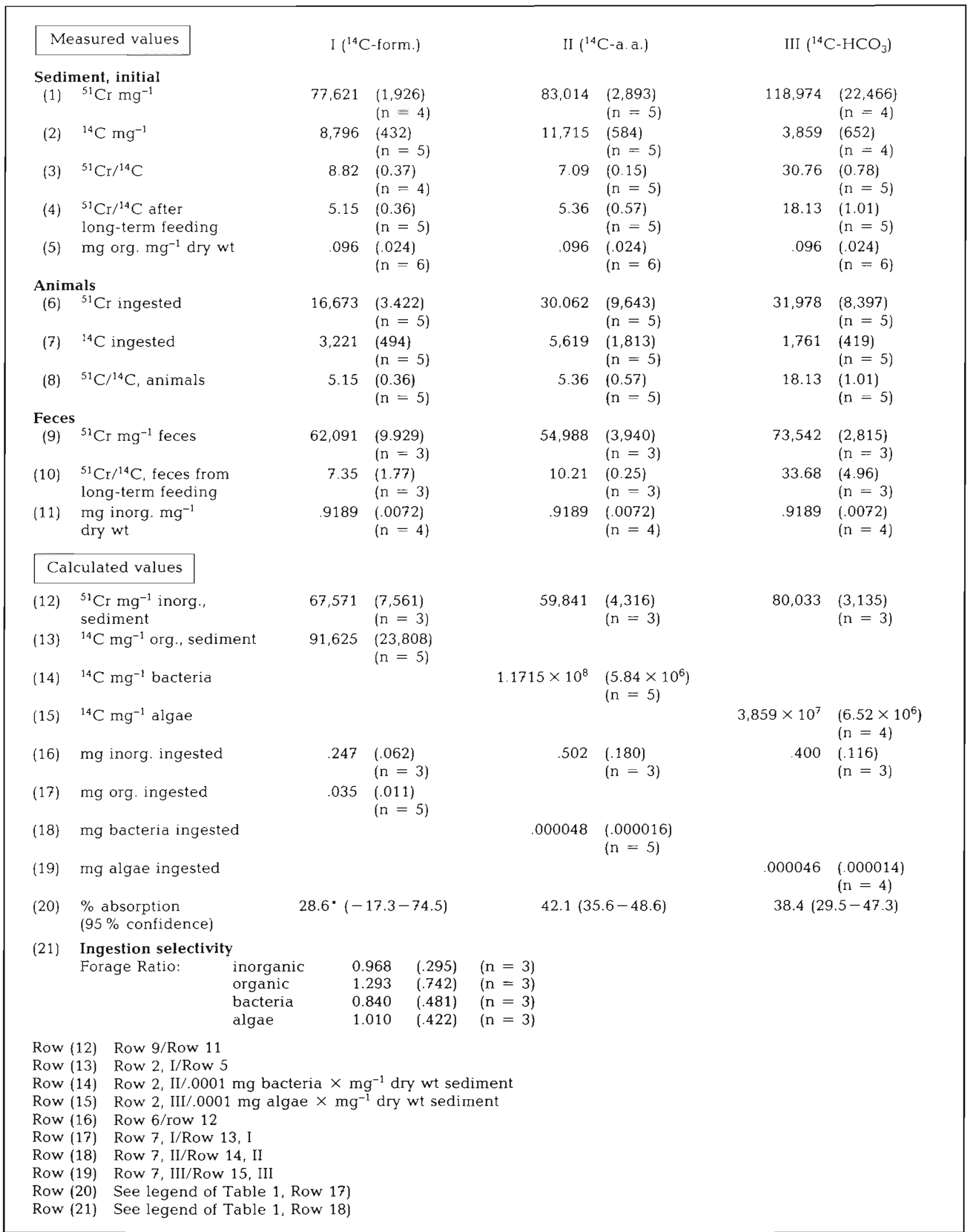


(Table 1, Rows 14 and 15). N. annulata absorbed approximately $10 \%$ of ingested ${ }^{51} \mathrm{Cr}$ adsorbed to sediment particles (Fig. 1).

Hydrobia totteni absorbed approximately $40 \%$ of both ingested bacteria and algae (Table 2, Row 20). The test animals did not selectively ingest either the organic, bacterial, or algal fraction from this silt-clay sediment (Table 2). Ingestion rate did not differ among the 3 treatments (Table 2, Rows 16 to 19). H. totteni absorbed approximately $4 \%$ of the ingested ${ }^{51} \mathrm{Cr}$ (Fig. 2).

\section{DISCUSSION}

\section{Feeding behavior}

Slightly different methods were used to estimate ingestion and absorption efficiency of Nucula annulata and Hydrobia totteni. We regard the Nucula experiment as better designed because the 'pulse-chase' pattern minimized problems of time-dependent changes in specific activity.

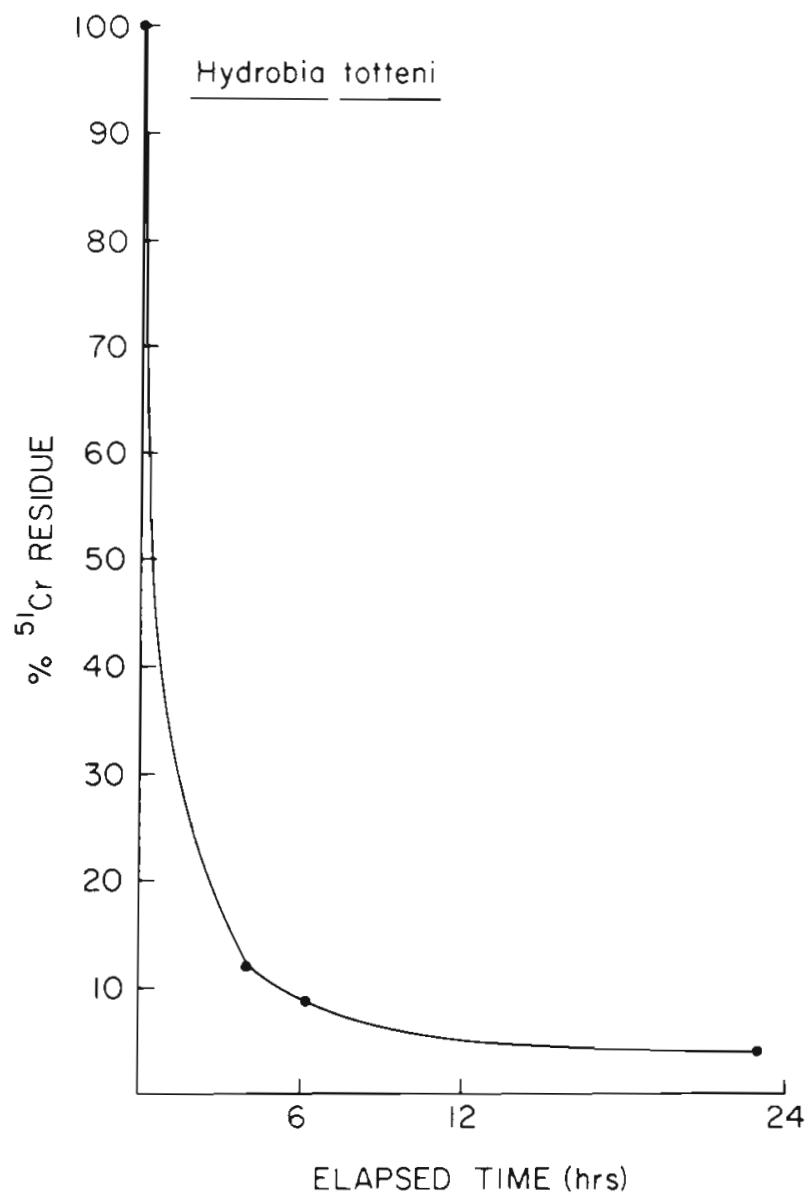

Fig. 2. Hydrobia totteni. Absorption of ingested ${ }^{51} \mathrm{Cr}$
Nucula annulata absorbed bacteria more efficiently than did Hydrobia totteni. To our knowledge, this is the first estimate of absorption efficiency for a protobranch bivalve. Its efficient utilization of sedimentassociated bacteria may be due to the combination of extracellular digestion with a long intestine (Owen, 1974). It is likely that relatively few bacteria are immune from such a digestive regime (Lopez, 1980). $H$. totteni probably has mostly intracellular digestion, so detachment and separation of cells from sediment particles is an important aspect of feeding (Lopez and Levinton, 1978). H. totteni appears to be very similar to other Hydrobia species in its ability to utilize microbes from ingested sediment (Kofoed, 1975; Lopez and Levinton, 1978).

Nucula annulata selected for ingestion those particles that were rich in both organic matter and bacteria. This finding suggests that bacteria in silt-clay are associated with the organic-rich particles. In earlier experiments with $N$. annulata, we did not see evidence of selective ingestion (Lopez and Cheng, 1982). This discrepancy may be due to improvements in experimental techniques; however, it also may point out that selectivity is not necessarily a species-specific trait, but may be modulated by sedimentological factors.

Hydrobia totteni fed indiscriminately on the offered sediment, although it is certainly capable of selective ingestion on other sediment types (Levinton, 1980, Lopez and Kofoed, 1980). H. totteni appeared to bite off and ingest large pieces of the cohesive mud; such a feeding mode may preclude much selection on cohesive sediments.

While we were not able to obtain paired measurements of ingestion rate and ingestion selectivity, inspection of the results indicates that ingestion selectivity is largely independent of ingestion rate for both Hydrobia totteni and Nucula annulata. Given the nature of our method for estimating ingestion selectivity, variations in selectivity would be seen in the ${ }^{51} \mathrm{Cr} /$ ${ }^{14} \mathrm{C}$ ratio of the ingested material. If ingestion selectivity was a function of ingestion rate, we would expect that variation in ingestion rate be reflected by variation in selectivity. In the Nucula experiment, the coefficients of variation for amounts of ${ }^{51} \mathrm{Cr}$ and ${ }^{14} \mathrm{C}$ ingested averaged approximately $40 \%$ (Table 1, Rows 5 and 6), while the $\mathrm{CV}$ of the ratio of ${ }^{51} \mathrm{Cr} /{ }^{14} \mathrm{C}$ ingested was close to $20 \%$ (Table 1, Row 7). The fact that the ingested ${ }^{51} \mathrm{Cr} /{ }^{14} \mathrm{C}$ ratio displayed rather low variation in animals that have fed at widely varying rates indicates that ingestion selectivity was independent of ingestion rate in these experiments. For these species, ingestion selectivity may be controlled mainly by morphological design of feeding organs and by sediment type.

We have calculated absorption of sedimentary 
organic matter, using the ${ }^{51} \mathrm{Cr} /{ }^{14} \mathrm{C}$ method. We have done this for the purposes of discussion only, because until the distribution of ${ }^{14} \mathrm{C}$ in the labelled has been characterized, conditions for estimating absorption efficiency have not been met. Nucula annulata did not appear to absorb ${ }^{14} \mathrm{C}$-formaldehyde labelled material ( $-2 \%$ efficiency), compared to $72 \%$ absorption of ${ }^{14} \mathrm{C}$-amino acid labelled bacteria (Table 1, Row 17). This finding suggests that ${ }^{14} \mathrm{C}$-formaldehyde labels mostly refractory organic compounds (Lopez and Crenshaw, 1982). The absorption estimate for $H$. totteni is higher (Table 2, Row 20), but the variance of the estimate was so large that no comment is possible.

\section{Comments on the experimental approach}

Robustness of our interpretations is based on how specific each procedure is in labelling its potential target food. The problem is complicated by the different requirements that must be met for ingestion and absorption estimates. For the latter, the label should be homogeneously distributed within the target food, and should not change in specific activity during the course of the experiment. These requirements are mutually exclusive for microbial foods, because if the label is homogenously distributed, some will necessarily be in a labile pool. It is likely that there can be no method of labelling with complete specificity for either bacteria or algae in sediments. The methods we have chosen will force us to miss many details, but we are convinced that these methods do differentially label identifiable potential foods, and that problems of adsorption, non-specific labelling, and time-dependent changes in activity have not proven so serious as to preclude interpretation.

Differential activities of bacteria during labelling cause a separate set of problems. We do not know either the proportion of the bacterial community labelled, or the activity of a particular labelled cell. This problem would be extremely serious if we were calculating food budgets of animals. Our goals are different. These techniques have been developed to study patterns of ingestion and absorption of natural foods in sediments. For the purposes of estimating ingestion rate and selectivity, we calculate ${ }^{14} \mathrm{C} /$ cell, using measured or assumed values of microbial abundance. The numerical value of this ratio is actually unimportant; it is simply a conversion factor. We do make the assumption, however, that animals do not ingest bacteria on the basis of activity. That is, ${ }^{14} \mathrm{C}$ cell ${ }^{-1}$ of swallowed bacteria is the same as that of the offered bacteria. The validity of this untested assumption is much more important to our conclusions than the actual ${ }^{14} \mathrm{C}$ cell ${ }^{-1}$ calculated in an experiment. Testing this assumption would be a major and very interesting project in itself, but it is not our present goal.

Evaluation of these preliminary experiments will lead to a more efficient experimental design. Estimation of weight-specific radioactivity in sediment samples was generally very good, but was much worse for fecal pellet samples. Gravimetric analysis of feces was poor because we were usually working with very small amounts. In future experiments many more pellets will be collected for gravimetric analysis.

Propagation of errors in the calculation of ingestion selectivity is a serious problem in this study, especially given the highly derived nature of the variance estimates. Our present technique is not sensitive enough to detect other than a high degree of selection or rejection, but experimental sensitivity can be improved by increasing sample size of gravimetric samples. Nevertheless, the following example demonstrates that the present method is a powerful tool in deposit-feeding studies. Cammen (1980b) concluded from an investigation of the polychaete Nereis succinea that organic detritus may be nutritionally important because ambient concentrations of microbes in sediment were apparently insufficient to support measured respiration rates. This conclusion was based on measurements of ingestion and respiration by the worms, and standing stocks of microbes in the sediment. Cammen discussed in some detail the problem of estimating the microbial richness of sediment ingested by $N$. succinea, which feeds by scraping off the surficial sediment. If the worms selected microbes only twice as well as they were thought to have done in that study (forage ratio $=2$ ), microbes would have appeared to have been a much more significant part of the diet. The method of estimating ingestion selectivity described in the present study is sensitive enough to detect such selectivity. This hypothetical exercise helps to demonstrate the usefulness of measuring ingestion selectivity, but we hope that the method can be greatly improved. Given the apparent insensitivity of selectivity to ingestion rate, it may be more economical to study selection in separate experiments where sampling can be appropriately scaled. The problems encountered here may also serve as a warning in interpreting other studies of ingestion selectivity in which there is no statistical analysis.

It is much easier to give an accurate estimation of absorption efficiency because the computation is based on measurements of ${ }^{51} \mathrm{Cr} /{ }^{14} \mathrm{C}$ ratios in animals and pellets. We were able to make good estimates of these ratios partly because gravimetric analysis was not involved.

We have developed this approach to ingestion selectivity because of our appreciation of the diversity of the ways that animals select food-rich particles for inges- 
tion (e.g. Self and Jumars, 1978; Lopez et al., 1979; Lopez and Kofoed, 1980; Taghon, 1982). Animals may select particles by size, shape, texture, specific gravity, taste, nutritive quality, or position in the sediment. For any given selective mechanism, for example by particle size, an experiment can be conducted to determine whether that mechanism is operating for a given animal-sediment combination. However, that mechanism may explain only a small subset of the animal's selective repertoire on a given sediment type (Lopez and Cheng, 1982). Our approach allows us to estimate the net result of the various modes of selection on ingestion of potential foods.

\section{Future applications}

We believe that the approaches described in this proposal will increase our understanding of the nature of deposit-feeding strategies. It is important to understand the potential and limitations of this approach. We are not attempting to construct food budgets for these species, not are we comparing specific feeding traits between species. That is, we are not primarily interested in determining whether one species ingests sediment more rapidly than another. We have developed this approach to determine whether sediment-microbe distributions affect the food-gathering abilities of animals having very different traits. The feeding strategy of a species will be characterized by determining how the suite of feeding traits are affected by different sediment types. We are particularly interested in sedimentological characteristics controlling microbial distribution and abundance. By comparing species or age groups that differ in morphological or behavioral traits, we will gain a better understanding of the adaptive nature of a given strategy.

Acknowledgements. We thank P. Calow, L. Cammen, D Capone, P. Jumars, R. Newell, G. Taghon, and 3 anonymous reviewers for commenting on drafts of this manuscript. This work was supported by NSF grant OCE8025345 to G. Lopez.

\section{LITERATURE CITED}

Calow, P. (1975). The feeding strategies of two freshwater gastropods, Ancylus fluviatilis Mull and Planorbis contortus Linn. (Pulmonata) in terms of ingestion rates and absorption efficiencies. Oecologia (Berl.) 20:33-49

Calow, P., Fletcher, C. R. (1972). A new radiotracer technique involving ${ }^{14} \mathrm{C}$ and ${ }^{51} \mathrm{Cr}$ for estimating the assimilation efficiency of aquatic primary producers. Oecologia (Berl.) 9: $155-170$

Cammen, L. M. (1980a). Ingestion rate: an empirical model for aquatic deposit feeders and detritivores. Oecologia (Berl.) 44: 303-310

Cammen, L. M. (1980b). The significance of microbial carbon in the nutrition of the deposit feeding polychaete Nereis succinea. Mar. Biol. 61: 9-20

Kofoed, L. H. (1975). The feeding biology of Hydrobia ventrosa (Montague). I. The assimilation of different components of food. J. exp. mar. Biol. Ecol. 19: 233-241

Levinton, J.S. (1980). Particle feeding by deposit-feeders: Models, data, and a prospectus. In: Tenore, K. R., Coull, B.C. (eds.) Marine benthic dynamics. University of South Carolina Press, Columbia, p. 423-439

Levinton, J. S., Bianchi, T S. (1981). Nutrition and food limitation of deposit-feeders. I. The role of microbes in the growth of mud snails (Hydrobiidae). J. mar. Res. 39: $531-545$

Lopez, G. R. (1980). The availability of microorganisms attached to sediment as food for some marine depositfeeding molluscs, with notes on microbial detachment due to the crystalline style. In: Tenore, K. R., Coull, B. C. (eds.) Maxine benthic dynamics. University of South Caroina Press, Columbia, p. 387-405

Lopez, G. R., Cheng, I-J. (1982). Ingestion selectivity of sedimentary organic matter by the deposit-feeder Nucula annulata (Bivalvia: Nuculidae). Mar. Ecol. Prog. Ser. 8: $279-282$

Lopez, G. R., Crenshaw, M. A. (1982). Radiolabelling of sedimentary organic matter with ${ }^{14} \mathrm{C}$-formaldehyde: preliminary evaluation of a new technique for use in depositfeeding studies. Mar. Ecol. Prog. Ser. 8: 283-289

Lopez, G. R., Kofoed, L. H. (1980). Epipsammic browsing and deposit-feeding in mud snails (Hydrobiidae). J. mar. Res. 38: 585-599

Lopez, G. R., Levinton, J. S. (1978). The availability of microorganisms attached for sediment particles as food for Hydrobia ventrosa (Montagu) (Gastropoda: Prosobranchia). Oecologia (Berl.) 32: 263-275

Lopez, G. R., Reimann, F., Schrage, M. (1979). Feeding biology of the brackish-water oncholaimid nematode Adoncholaimus thalassophygas. Mar. Biol. 54: 311-318

McCall, P. L. (1977). Community patterns and adaptive strategies of the infaunal benthos of Long Island Sound. J. mar. Res. 35: 221-266

Owen, G. A. (1974). Feeding and digestion in the Bivalvia. In: Lowenstein, $O$. (ed.) Advances in comparative physiology and biochemistry, Vol. 5. Academic Press, New York, p. $1-35$

Sanders, H. L. (1956). Oceanography of Long Island Sound, 1952-54. X. The biology of marine bottom communities. Bull. Bingham oceanogr. Coll. 15: 345-414

Self, R. F. L., Jumars, P. A. (1978). New resource axes for deposit feeders? J. mar. Res. 36: 627-641

Taghon, G. L. (1981). Beyond selection: optimal ingestion rate as a function of food value. Am. Nat. 118: 202-214

Taghon, G. L. (1982), Optimal foraging by deposit-feeding invertebrates: roles of particle size and organic coating Oecologia (Berl.) 52: 295-304

Wightman, J. A. (1975). An improved technique for measuring assimilation efficiency by the ${ }^{51} \mathrm{Cr} /{ }^{14} \mathrm{C}$ twin tracer method. Oecologia (Berl.) 19: 273-284 